\title{
Value Chain Analysis on SMEs Chips Product in Pematang Serai Village
}

\author{
Fitri Yani Panggabean ${ }^{1, *}$ Muhammad Bukhori Dalimunthe ${ }^{2}$ Surya Asih ${ }^{3}$ Ika Devi \\ Perwitasari ${ }^{4}$ Reza Aditia ${ }^{5}$ Raudah Zaimah Dalimunthe ${ }^{6}$
}

\author{
1,3,4 Universitas Pembangunan Panca Budi \\ ${ }^{2}$ Universitas Negeri Malang \\ ${ }^{5}$ Universitas Negeri Medan \\ ${ }^{6}$ Universitas Sultan Ageng Tirtayasa \\ ${ }^{*}$ Corresponding author. Email: fitriyani@dosen.pancabudi.ac.id
}

\begin{abstract}
This paper aims to analyze the value chain and to identify activities that have the highest economic value-added to the chips that are owned by the Small and Micro Enterprises (SMEs) of Pematang Serai Village, Langkat District. Value chain activities analyzed include: 1) supply of raw materials; 2) production process; 3) product sales; 4) marketing, which of these activities will be identified as the highest economic value so that SMEs obtain information to increase competitive advantage. Data collection uses content analysis instruments and in-depth interviews. The data analysis technique used in this study are descriptive statistics and content analysis. The results showed that the main activities of SMEs in Pematang Serai Village consisted of: 1) the supply of raw materials (casava) obtained from their gardens and suppliers and cooking oil obtained from suppliers; 2) chips production process using cooking equipment and product packaging; 3) product sales are carried out directly in private stores and also consignment; 4) marketing is done conventionally by displaying it in stores, no marketing has been done digitally. Value chain analysis in the highest economy is in product sales activities, this is because the dominant entrepreneurs produce chips so that they become featured products that are marketed outside the region. The implications of the findings of this study are to obtain the gaps to improve competitive advantage by utilizing more optimal and massive digital marketing by SMEs in this area.
\end{abstract}

Keywords: Allocated Village Fund, Transparency, Accountability

\section{INTRODUCTION}

Chips production business is not new in the culinary business. The business of chips is a business that is simple in terms of production, but complicated from the aspect of marketing. Some chips entrepreneurs acquire production skills from direct experience from the family. Dalimunthe and Panggabean [1] explained that the problem of entrepreneurs of chips lies in the mere production method and variety of flavors, resulting in uneven product quality.

In some regions, chips are spread massively and become a regional icon with a unique shape, taste, and name that adapts to the demographic characteristics of the area. Pematang Serai Village is one of the villages in Langkat District. The demographic position of the village, which is located on the crossing path between the Provinces of North Sumatra and Aceh has caused the village to become a stopover for residents traveling between provinces. The village community uses this for culinary production in the form of chips, sweets, and other traditional cakes. So many culinary products are offered, chips are a product that is in high demand by consumers and stable in the market. It is really interesting to examine the chips value chain because the product is an icon of Pematang Serai Village, and the chips offered are only original (plain). This study aims to conduct value chain analysis and identify the main activities that have the highest economic value.

The value chain is a product value-added caused by changes experienced by the product starting from raw materials, production processes, sales, to consumption. Hayami et al. [2] explained that value-added is a commodity value increase because there is a functional input on the commodity. Functional inputs are in the form of time utilities, place utilities, and time utilities. The value-added 
procedure uses a method developed by Hayami et al. [2], which is presented in table 1 .

Table 1. Value-Added Calculation Procedure

\begin{tabular}{|c|c|}
\hline Variable & Value \\
\hline \multicolumn{2}{|l|}{ I. Output, input, and price } \\
\hline Output (Kg/production) & A \\
\hline Raw material (Kg/production) & B \\
\hline Labor (Working day/production) & C \\
\hline Conversion Factor & $D=A / B$ \\
\hline Labor coefficient & $E=C / B$ \\
\hline Output price (Rp/Kg) & $\mathrm{F}$ \\
\hline $\begin{array}{l}\text { Average labor wage (Rp/Working } \\
\text { day) }\end{array}$ & G \\
\hline \multicolumn{2}{|l|}{ II. Income and profit } \\
\hline Sources of raw materials (Rp/Kg) & $\mathrm{H}$ \\
\hline Other input contributions (Rp/Kg) & I \\
\hline Output value & $J=D \times F$ \\
\hline Value-added & $K=J-I-H$ \\
\hline Value-added ratio & $L(\%)=(K / J) \times 100 \%$ \\
\hline & $M=E \times G$ \\
\hline Employee benefits & $N(\%)=(M / K) x$ \\
\hline Labor section & $100 \%$ \\
\hline & $\mathrm{O}=\mathrm{K}-\mathrm{M}$ \\
\hline Profit & $P(\%)=(O / K) X$ \\
\hline Profit level & $100 \%$ \\
\hline \multicolumn{2}{|l|}{ III. Remuneration for production factors } \\
\hline Margin & $Q=J-H$ \\
\hline Profit & $\begin{array}{l}R(\%)=(O / Q) \times \\
100 \%\end{array}$ \\
\hline Labor & $\begin{array}{l}S(\%)=(M / Q) \times \\
100 \%\end{array}$ \\
\hline Other Input & $\mathrm{T}(\%)=(\mathrm{I} / \mathrm{Q}) \times 100 \%$ \\
\hline
\end{tabular}

\section{LITERATURE REVIEW}

Value chains are a way for companies to find out the chain of activities in turning raw materials into products that are valuable to consumers. Pears and Robinson [3] explain the value for customers consists of three primary activities, namely; (1) activities to differentiate products; (2) activities reduce costs; and (3) activities meet consumer needs. Value chain analysis seeks to find out how companies create value to meet consumer needs by contributing to different activities. The complexity of activities, the ability to collect transactions, and the ability to provide supplies, are very important elements to form a value chain structure [4].

Not only oriented to value-added from each of the different activities, but the value chain also includes aftersales services, as revealed by Shank and Govindarajan [4] that value chain analysis is a tool to understand the value used to create a product. The value chain comes from activities carried out by the company, ranging from raw materials to consumption by customers, including after-sales services.

Value chain analysis can be used to determine competitive advantage strategy decisions. Competitive advantage strategies can use low-cost strategies and differentiation strategies [5]. There has been a lot of research discussing value chains focusing on economic sustainability, so strategic and operational alignments are needed in managing resources to achieve competitive advantage [6]. Both of these strategies focus on analyzing the value chain of input to output production activities. Companies in business competition need product innovations that are following customer needs so that new ideas are needed in creating products, which results in the need for strategies to reduce inefficiencies.

The business core of each company is different; some operate as service, trading, and manufacturing companies. So that there are differences in the value chain of each business core. Manufacturing companies have more complex value chains than other business operations.

\section{METHODS}

The research respondents were 26 entrepreneurs who sold chips in Pematang Serai Village. Data collection used content analysis instruments and in-depth interviews, while data analysis techniques used descriptive statistics, valueadded analysis, and content analysis of the main activities of the respondents.

\subsection{Value-Added Analysis}

The value-added analysis procedure uses a method developed by Hayami [2] which consists of (1) analysis of product output, input, and price; (2) income and profits; and (3) remuneration for production factors. The value-added analysis is used to find out the product value chain from raw materials, processes, to goods ready for sale. Then further studies can be carried out using additional treatment of products by diversifying products with a variety of flavors.

\subsection{Content Analysis}

Content analysis is used to identify the main activities that have optimal value-added, which consists of (1) supply of raw materials; (2) production process; (3) product sales; and (4) marketing. Information obtained from content analysis takes the form of the highest economic activity and efforts to maximize product value-added from the main activity.

\section{RESULTS AND DISCUSSIONS}

Based on data collection that has been done, and in-depth interviews with respondents, the results obtained are described as follows. 


\subsection{Respondent Description}

The identity of the respondents can be seen in Table 2 .

Table 2. Respondent Description

\begin{tabular}{|c|c|c|}
\hline Description & Amount & Percentage (\%) \\
\hline \multicolumn{3}{|l|}{ Gender } \\
\hline Male & 8 & 30,77 \\
\hline Female & 18 & 69,23 \\
\hline \multicolumn{3}{|l|}{ Age (year) } \\
\hline Under 20 & 0 & 0 \\
\hline $20-30$ & 5 & 19,23 \\
\hline $31-40$ & 14 & 53,85 \\
\hline $41-50$ & 5 & 19,23 \\
\hline Over 50 & 2 & 7,69 \\
\hline \multicolumn{3}{|l|}{ Marital status } \\
\hline Married & 22 & 84,62 \\
\hline Single & 0 & 0 \\
\hline Widow/widower & 4 & 15,38 \\
\hline \multicolumn{3}{|l|}{ Monthly sales (Rp) } \\
\hline Under 1.000 .000 & 8 & 30,77 \\
\hline $1.000 .001-2.000 .000$ & 10 & 38,46 \\
\hline $2.000 .001-3.000 .000$ & 6 & 23,08 \\
\hline $3.000 .001-4.000 .000$ & 2 & 7,69 \\
\hline $4.000 .001-5.000 .000$ & 0 & 0 \\
\hline Over 5.000 .000 & 0 & 0 \\
\hline \multicolumn{3}{|c|}{$\begin{array}{l}\text { Ever attended production } \\
\text { training }\end{array}$} \\
\hline Yes & 2 & 7,69 \\
\hline No & 24 & 92,31 \\
\hline \multicolumn{3}{|l|}{ Product variation } \\
\hline Original (plain) & 22 & 76,92 \\
\hline Hot & 0 & 0 \\
\hline Sweet & 0 & 0 \\
\hline Salty & 4 & 23,08 \\
\hline
\end{tabular}

Based on data collection that has been done and in-depth interviews with respondents, the results will be described as follows.

Women dominate gender characteristics; this explains that women are very contributory in helping the family economy. Most sales made by respondents are in the range of Rp. 1,000,001 to Rp. 2,000,000, this explains that microentrepreneurs still dominate respondents with limited financial resource capabilities. Respondents' activities in participating in production training provided by government or private institutions are still shallow, with only $7.69 \%$, this indicates that SME players in producing chips are still selftaught from past experience so that they are vulnerable to inferior product quality. This problem is also in line with the variety of products produced by the respondents, in which product variations are dominated by original (plain) chips of $76.92 \%$ while the rest are variations in salty taste products.
The lack of training and knowledge of product diversification will result in stagnant products in the market, resulting in weaker product competitiveness in the market. Product diversification, application of technology, innovation, and creativity are works that must be made by entrepreneurs to be able to have competitiveness in the market [1].

\subsection{Value-Added Analysis}

The results of the value chain analysis are presented in Table 3 .

Table 3. Calculation of Chips Value-Added

\begin{tabular}{|c|c|c|}
\hline Variable & Original & $\begin{array}{c}\text { Taste } \\
\text { Variation }\end{array}$ \\
\hline \multicolumn{3}{|l|}{ I. Output, input, and price } \\
\hline Output (Kg/production) & 15,50 & 15,50 \\
\hline Raw material (Kg/production) & 20,00 & 20,00 \\
\hline Labor (Working day/production) & 2,00 & 2,00 \\
\hline Conversion Factor & 0,78 & 0,78 \\
\hline Labor coefficient & 0,10 & 0,10 \\
\hline Output price (Rp/Kg) & $20.000,00$ & $25.000,00$ \\
\hline $\begin{array}{l}\text { Average labor wage } \\
\text { (Rp/Working day) }\end{array}$ & $25.000,00$ & $25.000,00$ \\
\hline \multicolumn{3}{|l|}{ II. Income and Profit } \\
\hline Sources of raw materials (Rp/Kg) & $2.000,00$ & $2.000,00$ \\
\hline Other input contributions & & \\
\hline$(\mathrm{Rp} / \mathrm{Kg})$ & $3.500,00$ & $5.000,00$ \\
\hline \multicolumn{3}{|l|}{ Output value } \\
\hline Value-added & $15.500,00$ & $19.375,00$ \\
\hline Value-added ratio & $10.000,00$ & $12.375,00$ \\
\hline Employee benefits & 64,52 & 63,87 \\
\hline Labor section & $2.500,00$ & $2.500,00$ \\
\hline Profit & 25,00 & 20,20 \\
\hline \multirow[t]{2}{*}{ Profit level } & $7.500,00$ & $9.875,00$ \\
\hline & 48,39 & 50,97 \\
\hline \multicolumn{3}{|c|}{ III. Remuneration for production factors } \\
\hline Margin & $13.500,00$ & $17.375,00$ \\
\hline Profit & 55,56 & 56,83 \\
\hline Labor & 18,52 & 14,39 \\
\hline Other Input & 25,93 & 28,78 \\
\hline
\end{tabular}

Based on Table 3, information is obtained that the valueadded of the original chips product is Rp. 10,000 and a margin of Rp. 13,500. The value-added obtained by respondents through the production of raw materials (cassava) into chips is quite optimal with a profit rate of $55.56 \%$. Cassava chips processing agroindustry has value-added which can be marketed in a consumption period of around two months so that the production and marketing cycles are sufficiently maintained [7].

Product diversification carried out by several respondents (23.08\%; see Table 2) with a variety of flavors resulted in a 
significant increase with value-added of Rp. 12,375 and a margin of Rp. 17,375. Increasing economic value with the knowledge and skills of respondents through product diversification of salty flavors has given an increase of $1.27 \%$ of the profit level compared to original (plain) flavored chips. The addition of product variants from aspects of shape, taste, and packaging aims to reach untouched market segments [8].

\subsection{Content Analysis} 4.

The results of the content analysis are presented in Table

Table 4. Calculation Of Content Analysis Of Original Flavored Chips Production

\begin{tabular}{|l|l|r|r|}
\hline \multicolumn{1}{|c|}{$\begin{array}{c}\text { Primary } \\
\text { Activities }\end{array}$} & \multicolumn{1}{|c|}{$\begin{array}{c}\text { Value } \\
\text { (capacity 20 kg) }\end{array}$} & \multicolumn{1}{c|}{$\begin{array}{c}\text { Estimation } \\
\text { (Rp) }\end{array}$} \\
\hline $\begin{array}{l}\text { Provision of raw } \\
\text { materials }\end{array}$ & Casava & 40.000 & 2.000 \\
\hline Production & Seasoning & 3.500 & 2.675 \\
process & Fuel & 20.000 & \\
& Packaging & 5.000 & \\
& Labor & 25.000 & \\
\hline Product sales & Fee & 50.000 & 2.500 \\
& Consignment & 10.000 & 500 \\
\hline Marketing & Transportation & & \\
\hline Total cost & & 0 \\
\hline Price/kg & & 7.675 \\
\hline Profit margin & & 20.000 \\
\hline
\end{tabular}

Based on the data presented in Table 4, information is obtained that the main activity in the form of product sales is the highest economic value. This condition is due to consignment sales techniques and unavailability of privately owned stores. The main activity in the marketing aspect has not been optimized, so product marketing is only limited to Pematang Serai Village. Companies must be able to know their position in the value chain that forms the product or service produced [9]. Complex competition must be meticulously responded by entrepreneurs so that innovation and appropriate strategies are needed to create a competitive advantage [10].

With such conditions, it is necessary to form a competitive advantage strategy in the form of effective and efficient marketing optimization by utilizing digital marketing. So much cost-efficient social media can be used to market products and effectively provide a business profile and product information to consumers so that it can reduce costs, which will have an impact on increasing profits.

\section{CONCLUSION}

The chain analysis of the value of the entrepreneurs of cassava chips is concluded to have competitive value-added. Diversification of products with a variety of flavours has been shown to increase profit margins compared to original flavoured chips. However, the limitations of the knowledge and

Skills of the chips entrepreneurs to produce various flavors of chips have made it difficult for entrepreneurs to innovate products.

The main activity that has the highest economic value lies in product sales, while marketing activities do not yet exist. The research findings in this study imply that there are gaps to increase sales margins by utilizing optimal and massive digital marketing that can be done by entrepreneurs.

\section{ACKNOWLEDGMENT}

The authors are grateful to the Directorate of Research and Community Service, Ministry of Research, Technology and Higher Education who has provided funding through the Community Service scheme in 2019.

\section{REFERENCES}

[1] M.B. Dalimunthe, F.Y. Panggabean, Maximazing Revenue and Competitive Advantage of Small And Medium-Sized Enterprises in Binjai, Indonesia: A Community Service Study, Proceedings, Malang: Faculty of Economy Universitas Negeri Malang, [International Conference on Education for Economics, Business, and Finance (ICEEBF)], 2016, pp 165-169.

[2] Y. Hayami, T. Kawagoe, Y. Morooka, M. Siregar, Agricultural Marketing and Processing in Upland Java: A Perspective from a Sunda Village, Bogor: The CPGRT Centre, 1987.

[3] J. A. Pearce II, R. B. Robinson, Strategic ManagementFormulation, Implementation and Control, International Edition, USA: Mc Graw-Hill, 2009.

[4] G. Gereffi, J. Humphrey, T. Sturgeon, The governance of global value chains, Review of International Political Economy, London: Taylor and Francis Group, vol. 12 (1), 2006, pp. 78-104.

[5] J.K. Shank, V. Govindarajan, Strategic Cost Management and the Value Chain, United States: Thomson Learning, 2000.

[6] A. Fearne, M.G. Martinez, B. Dent, Dimensions of sustainable value chains: implications for value chain analysis, Supply Chain Management, UK: Emerald Publishing, vol. 17(6), 2012, pp. 575-581.

[7] M. Hamidah, A.H.A. Yusra, J. Sudrajat, Analisis Nilai Tambah Agroindustri Kripik Ubi di Kota Pontianak, Jurnal Social Economic of Agriculture, Pontianak: Fakultas Sosial Ekonomi Universitas Tanjungpura, vol. 4(2), 2015, pp. 60-73.

[8] H. Hapsari, E. Djurwendah, T. Karyani, Peningkatan Nilai Tambah dan Strategi Pengembangan Usaha Pengolahan Salak Manonjaya., Jurnal Agrikultura, Bandung: Fakultas Pertanian Universitas Padjajaran, vol. 19 (3), 2008, pp. 208-215. 
[9] O. Wisdaningrum, Analisis Rantai Nilai (Value Chain) Dalam Lingkungan Internal Perusahaan, Analisa, Bandung: Department of Mathematics Education, Faculty of Tarbiyah and Teacher Training, UIN Sunan Gunung Djati Bandung, vol. 1 (1), 2013, pp. 40-48.

[10] M. B. Dalimunthe, Keunggulan Bersaing Melalui Orientasi Pasar dan Inovasi Produk, Jurnal Konsep
Bisnis dan Manajemen, Medan: Management Study Program Faculty of Economics and Business, University of Medan Area, vol. 3 (2), 2017, pp. 18-31. 